\title{
DETECTING THE ANTI-STREPTOCOCCUS PYOGENS ACTIVITY OF CYANOBACTERIUM (APHANOCAPSA SPECIES) BY USING PLACKETT- BURMAN EXPERIMENTAL DESIGN
}

\author{
Amira, M. El Farakh'; Ragaa, A. Hamouda ${ }^{1}$; Mohamed, O. Abdel Fatah² ;Saad, I. \\ Amar $^{3}$ \\ ${ }^{1}$ Microbial biotechnology department Genetic Engineering \&Biotechnology Institute . \\ University Of EL Sadat City, \\ ${ }^{2}$ Molecular Biology, Genetic Engineering \& Biotechnology Institute University Of EL \\ Sadat City. \\ ${ }^{3}$ Faculty of Medicine, Banha University.
}

\begin{abstract}
Streptococcus pyogenes is associated with a wide range of infections and disease states, that infects children and adolescents causing sore throat. This study was carried out to evaluate the potential of exopolysaccharides of Aphanocapsa sp was tested for antibacterial activity against Streptococcus pyogenes ( Group A streptococcus) bacterial cultures using well diffusion method.Plackett- Burman design was applied on original BG11medium to determine the best conditions that effect on activity of exopolysaccharides of Aphanocapsasp against Streptococcus pyogenes. Plackett- Burman design was performed on original BG11medium by applied various nitrogen sources $\mathrm{NaNO}_{3}$ and ammonium chloride. It was found that exopolysacchaaride extracted from Aphanocapsa $s p$ had activity against Streptococcus pyogenes. Exopolysacchaaride extracted from alga that grown in Bg11medium supplemented with ammonium chloride had more effective against Streptococcus pyogenes than that obtained from $\mathrm{Bg} 11$ medium supplemented with $\mathrm{NaNO}_{3}$.
\end{abstract}

Key Words : Antibacterial, Aphanocapsa sp. ,Streptococcus pyogenes, cyanobacteria, Plackett- Burman design.

\section{INTRODUCTION}

Streptococcus pyogenes diseases remain a major public health problem in developing countries, reaching 600 million cases per year and thus constituting an important cause of morbidity and mortality (PUB MED) . Group A streptococci (GAS) infections can lead to severe invasive diseases including pharyngitis and pyoderma and to autoimmune poststreptococcal sequelae, such as rheumatic fever (RF) and glomerulonephriti (Wikipedia ).This increase of antibiotic resistant bacteria is a serious issue because of the constant concern of reduced efficiency of antibiotics in the treatment of human diseases (Chandruet al 2013).Isolation of bioactive compounds from cyanobacteria is done with two objectives: one is to discover new compounds for pharmaceutical, agricultural or biological application; the other is for the better understanding of the interactions of individual organisms within their natural communities. For each of these purposes, there is a need to screen new organisms (Rania and Hala, 2008). The ability to produce antimicrobial substances may be attributed to the defensive nature to survive in different habitats of the species and also a good source of new bioactive compounds (Rania and Hala, 2008). Cyanobacteria, known as blue-green algae include a highly diverse group of prokaryotic microorganisms and widely distributed in nature and can be found in most terrestrial and freshwater habitat (Potts, 2002). Cyanobacteria is considered to be one of the potential organisms and useful to mankind in various ways. A number of important advances have occurred in cyanobacterial biotechnology in the recent years.(RizviRimsha et al.2014). Cyanobacteria produce many bioactive compounds, both intra- and extracellular to 
survive in extreme environmental sources (Dvornyk and Nevo, 2003;Kulik, 1995; Kreitlow et al.,1999; Patterson et al.,1994). Recently, microalgae have become particularly interesting because of the possibility to easily control the growth conditions in a bioreactor together with the demonstrated biochemical diversity of these organisms (Akmjmop et al., 2015). Greater screening and selection efforts for biologically active compounds, including polysaccharides, have been developed ( DePauw and Persoone, 1988 ). Exopolysaccharides in pharmaceutical industry they can be used as antiviral (Hayashi et al., 1996 a, b; Singh and Das, 2011), Microbial Exopolysaccharides (EPSs) are

biosynthetic polymers mainly consisting of carbohydrates secreted by bacteria (Freitaset et al., 2009) and cyanobacteria (Parikh and Madamwar, 2006).

\section{MATERIALS AND METHODS \\ Cyanobacterial strain isolation and identification:}

Cyanobacterial strain was isolated from cultivated rice fields in ElGharbia district,Egypt.Culture purification was according to Andersen (2005), Van Landingham and Collins (1982).

\section{Culture conditions:}

Aphanocapsaspwas grown in axenic cultures at $28 \pm 2{ }^{\circ} \mathrm{C}$. under continuous illumination $(50 \mu \mathrm{mol}$ photons $\mathrm{m}-2 \mathrm{~s}-1)$ in $500 \mathrm{~mL}$ conical flasks, containing $200 \mathrm{~mL}$ BG11media (Steiner et al 1971) then to apply Plackett-Burman design.

Firstly: Total eight variables from BG-11 were screened include $\mathrm{NaNO}_{3}$, $\mathrm{K}_{2} \mathrm{HPO} 4, \mathrm{MgSO}_{4} \cdot 7 \mathrm{H}_{2} \mathrm{O}, \mathrm{CaCl}_{2} \cdot 2 \mathrm{H}_{2} \mathrm{O}$, citric acid, ferric ammonium citrate, EDTA and $\mathrm{Na}_{2} \mathrm{CO}_{3}$.

Secondly : thePlackett-Burman design was applied withNH $\mathrm{N}_{4} \mathrm{Cl}$ as nitrogen source instead of $\mathrm{NaNo}_{3}$.

Plackett-Burman (PB) designs are a class of fractional factorial designs first developed by two mathematicians/statisticians (Plackett and Burman 1946) A Plackett-Burman, which is traditionally used for identifying important factors from many potential factors.

Table 1.Effect of the components of BG-11 medium on algal growth using the Plackett-Burman multifactorial design.

\begin{tabular}{|c|c|c|c|c|c|c|c|c|}
\hline \multirow[t]{3}{*}{ Trial } & \multicolumn{2}{|l|}{ 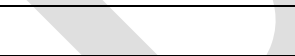 } & \multicolumn{6}{|c|}{ Level and concenteration of variable $(\mathrm{g} / \mathrm{l})$} \\
\hline & $\mathrm{X} 1$ & $\mathrm{X}_{2}$ & $\mathrm{X}_{3}$ & $\mathrm{X}_{4}$ & $\mathrm{X}_{5}$ & $\mathrm{X}_{6}$ & $\mathrm{X}_{7}$ & $\mathrm{X}_{8}$ \\
\hline & $\mathrm{NaNO}_{3}$ & $\mathrm{~K}_{2} \mathrm{HPO}_{4}$ & $\begin{array}{c}\mathrm{MgSo}_{4} \cdot 7 \mathrm{H} \\
{ }_{2} \mathrm{O} .\end{array}$ & $\begin{array}{c}\mathrm{CaC}_{2} \cdot 2 \mathrm{H} \\
{ }_{2} \mathrm{O}\end{array}$ & $\begin{array}{c}\text { Citric } \\
\text { acid }\end{array}$ & $\begin{array}{c}\text { Ferric } \\
\text { ammoniu } \\
\text { m citrate }\end{array}$ & EDTA & $\begin{array}{c}\mathrm{Na}_{2} \mathrm{Co} \\
3\end{array}$ \\
\hline $\mathrm{T}_{1}$ & +2.25 & -0.02 & +0.1125 & -0.018 & -0.003 & -0.003 & +0.0015 & +0.03 \\
\hline $\mathrm{T}_{2}$ & +2.25 & +0.06 & -0.0375 & +0.054 & -0.003 & -0.003 & -0.0005 & +0.03 \\
\hline $\mathrm{T}_{3}$ & -0.75 & +0.06 & +0.1125 & -0.018 & +0.09 & -0.003 & -0.0005 & -0.01 \\
\hline $\mathrm{T}_{4}$ & +2.25 & -0.02 & +0.1125 & +0.054 & -0.003 & +0.09 & -0.0005 & -0.01 \\
\hline $\mathrm{T}_{5}$ & 2.25 & +0.06 & -0.0375 & +0.054 & +0.09 & -0.003 & +0.0015 & -0.01 \\
\hline $\mathrm{T}_{6}$ & +2.25 & +0.06 & +0.1125 & -0.018 & +0.09 & +0.09 & -0.0005 & +0.03 \\
\hline $\mathrm{T}_{7}$ & -0.75 & +0.06 & +0.1125 & +0.054 & -0.003 & +0.09 & +0.0015 & -0.01 \\
\hline $\mathrm{T}_{8}$ & 0.75 & -0.02 & +0.1125 & +0.054 & +0.09 & -0.003 & +0.0015 & +0.03 \\
\hline $\mathrm{T}_{9}$ & -0.75 & -0.02 & -0.0375 & +0.054 & +0.09 & +0.09 & -0.0005 & +0.03 \\
\hline $\mathrm{T}_{10}$ & 2.25 & -0.02 & -0.0375 & -0.018 & +0.09 & +0.09 & +0.0015 & -0.01 \\
\hline $\mathrm{T}_{11}$ & -0.75 & +0.06 & -0.0375 & -0.018 & -0.003 & +0.09 & +0.0015 & +0.03 \\
\hline $\mathrm{T}_{12}$ & -0.75 & -0.02 & -0.0375 & -0.018 & -0.003 & -0.003 & -0.0005 & -0.01 \\
\hline $\mathrm{T}_{13}$ & 1.5 & 0.04 & 0.075 & 0.036 & 0.006 & 0.006 & 0.01 & 0.02 \\
\hline
\end{tabular}




\section{Exopolysaccharide}

(EPs) extraction: After culture centrifugation (4,500 g, $10 \mathrm{~min})$ the EPS was precipitated by an equal volume of isopropanol, filtered and dried at $37^{\circ} \mathrm{C}$ (Reddy et al., 1996; Pawaret al., 2013).

Screening of anti-Streptococcu spyogenes ( ATCC 19615 ) activity of Aphanocapsa sp.

This was done by using well diffusion method on blood trypticase soy agar medium andaccording to ( Chandru et al 2013). The diameter of inhibition zone around each well was measured which shows non hemolysis (non rupturing of red blood cells) While The rest ofthe plate shows beta hemolysis (complete rupturing of red blood cells) visible as a halo in culture.

\section{RESULTS AND DISCUSSION}

In order to find out the key ingredients significantly affecting bioactivity and biomass production, a Plackett-Berman design was carried out and Minitab 16 software used to analyze the results.

Effect the components of BG-11 medium on algal growth using $\mathrm{NaNO}_{3}$ as nitrogen source

Table 2. Estimated effects and coefficients for analysis of Plackett-Burman design on EXP

\begin{tabular}{|l|l|l|l|l|l|}
\multicolumn{5}{|c}{ g/L } \\
Term & Effect & Coef & SE Coef & T & P \\
\hline Constant & & 0.00000 & 0.01263 & 0.00 & 1.000 \\
\hline $\mathrm{NaNo}_{3}$ & -0.00000 & -0.00000 & 0.01263 & -0.00 & 1.000 \\
\hline $\mathrm{K}_{2} \mathrm{HPO}_{4}$ & -0.00000 & -0.00000 & 0.01263 & -0.00 & 1.000 \\
\hline $\mathrm{MgSO}_{4} .7 \mathrm{H}_{2} \mathrm{O}$ & -0.00000 & -0.00000 & 0.01263 & -0.00 & 1.000 \\
\hline $\mathrm{CaCl}_{2} .2 \mathrm{H}_{2} \mathrm{O}$ & -0.00000 & -0.00000 & 0.01263 & -0.00 & 1.000 \\
\hline Citric acid & -0.00000 & -0.00000 & 0.01263 & -0.00 & 1.000 \\
\hline Ferric ammonium citrate & 0.00000 & 0.00000 & 0.01263 & 0.00 & 1.000 \\
\hline EDTA & -0.00000 & -0.00000 & 0.01263 & -0.00 & 1.000 \\
\hline $\mathrm{Na}_{2} \mathrm{Co}_{3}$ & -0.00000 & -0.00000 & 0.01263 & -0.00 & 1.000 \\
\hline
\end{tabular}

Data in table 2 indicate that all the media components were showed nonsignificance for the Exopolysaccharides $(\mathrm{EXP})$ production $(\mathrm{P}-$ value $>0$. 5). These variables correlates negatively with it, highconcentration of these variables inhibits (EXP) production by Aphanocapsa $s p$ except Ferric ammonium citrate correlates positively, highconcentration of this variable promote (EXP) productionby Aphanocapsa sp.The coeffient value for all variables is zero indicating independent variables. 


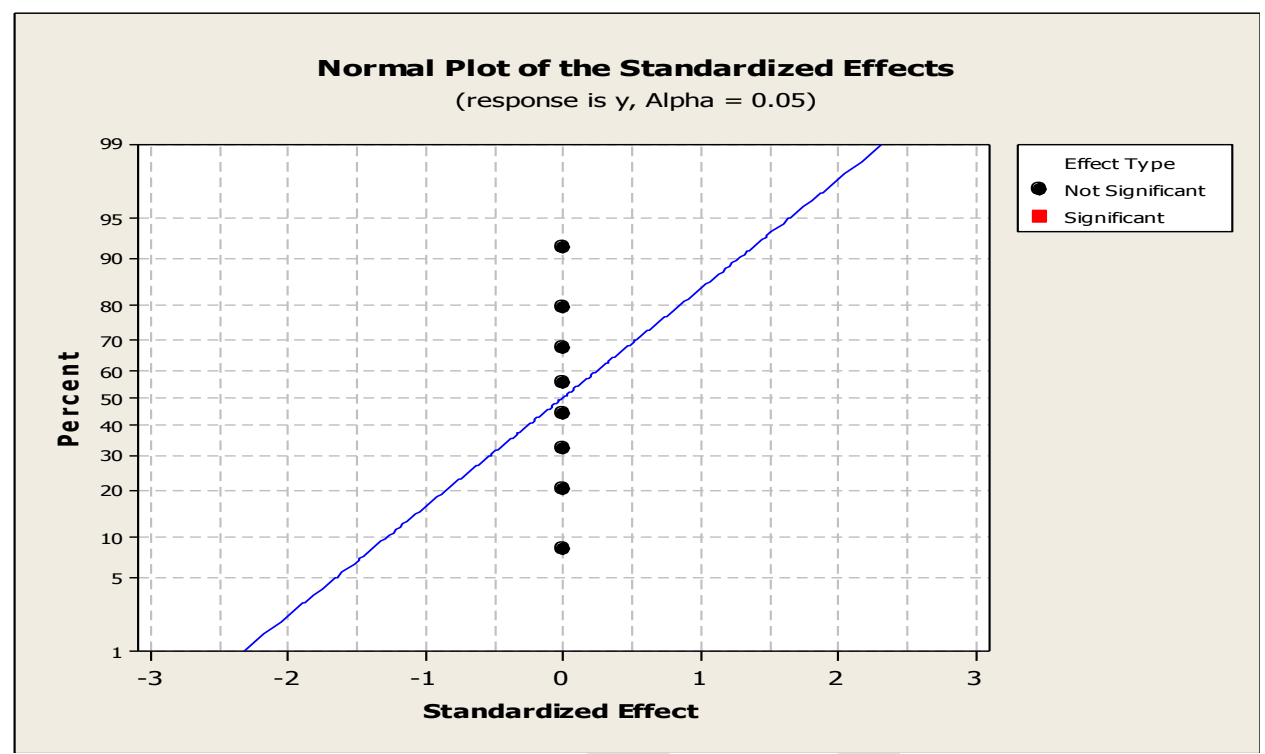

Fig.1.Normal plot of Estimated effects for analysis of Plackett-Burman design on (EXP) production.

The normal probability plot displays negative effects on the left side of the graph graph. The above plot shows the and positive effects on the right side of the independent variables on zero.

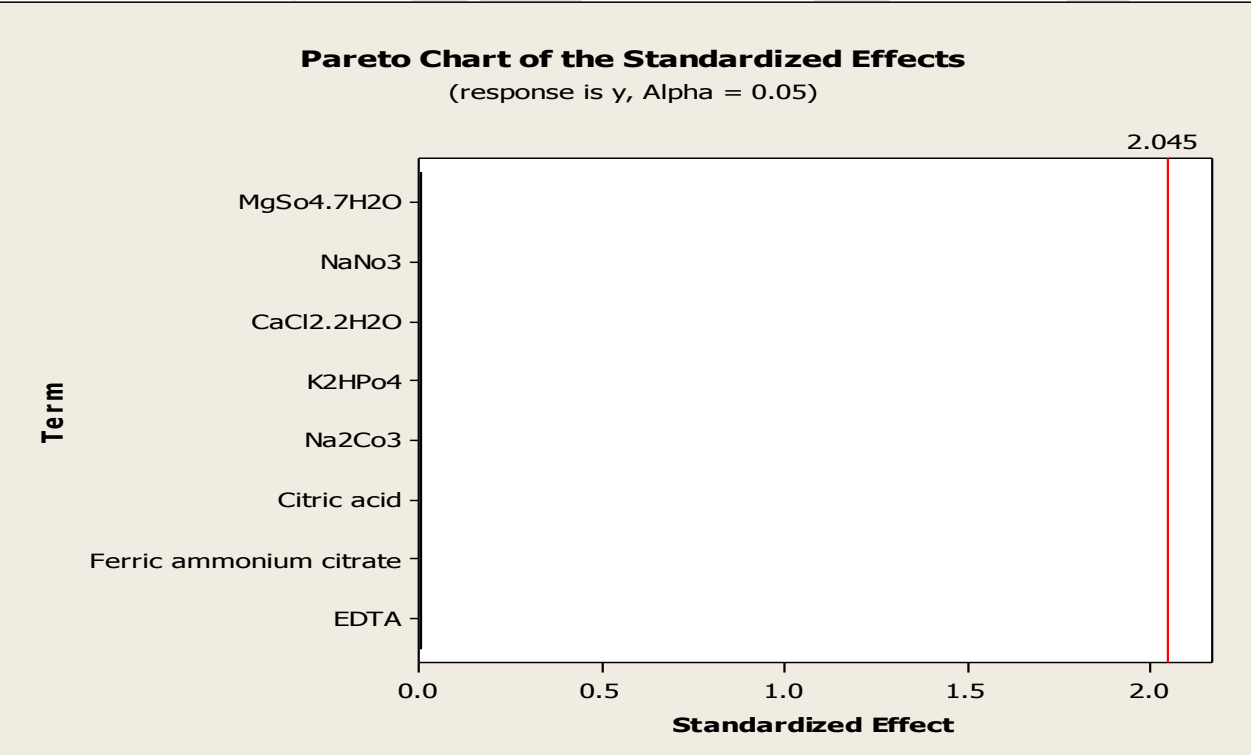

Fig.2 Pareto chart of estimated effects for analysis of Plackett-Burman design on (EXP) production.

Thepareto chart shows that there are no effect of the eight variables on the production of (EXP) by Aphanocapsaspthis is due to the pareto charts are ranking the factors according to its effects and significance. 
Table 3. Estimated effects and coefficients for analysis of Plackett-Burman design on antibacterial activity production.

\begin{tabular}{|l|l|l|l|l|l|}
\hline Term & Effect & Coef & SE Coef & T & P \\
\hline Constant & & 562.50 & 16.80 & 33.48 & 0.000 \\
\hline $\mathrm{NaNO}_{3}$ & 105.00 & 52.50 & 16.80 & 3.12 & 0.004 \\
\hline $\mathrm{K}_{2} \mathrm{HPO}_{4}$ & -45.00 & -22.50 & 16.80 & -1.34 & 0.191 \\
\hline $\mathrm{MgSo}_{4} \cdot 7 \mathrm{H}_{2} \mathrm{O}$ & 91.67 & 45.83 & 16.80 & 2.73 & 0.011 \\
\hline $\mathrm{CaCl}_{2} \cdot 2 \mathrm{H}_{2} \mathrm{O}$ & 48.33 & 24.17 & 16.80 & 1.44 & 0.161 \\
\hline Citric acid & -56.67 & -28.33 & 16.80 & -1.69 & 0.102 \\
\hline Ferric ammonium citrate & -53.33 & -26.67 & 16.80 & -1.59 & 0.123 \\
\hline EDTA & -81.67 & -46.67 & 16.80 & -2.78 & 0.010 \\
\hline $\mathrm{Na}_{2} \mathrm{Co}_{3}$ & -93.33 & -40.83 & 16.80 & -2.43 & 0.022 \\
\hline
\end{tabular}

The data presented in table 3 clearly show that p-values indicates that $\mathrm{NaNo}_{3}$, EDTA, $\mathrm{MgSo}_{4} .7 \mathrm{H}_{2} \mathrm{O}$ and $\mathrm{Na}_{2} \mathrm{Co}_{3}$ are significant variables, Citric acid, Ferric ammonium citrate, $\mathrm{CaCl}_{2} \cdot 2 \mathrm{H}_{2} \mathrm{O}$ and $\mathrm{K}_{2} \mathrm{HPo}_{4}$ are nonsignificant variables. Furthermore, the positive correlation obtained by $\mathrm{NaNo}_{3}, \mathrm{MgSo}_{4} .7 \mathrm{H}_{2} \mathrm{O}$,

$\mathrm{CaCl}_{2} \cdot 2 \mathrm{H}_{2} \mathrm{O}$ and a negative correlation for $\mathrm{K}_{2} \mathrm{HPo}_{4}$,Citric acid,Ferric ammonium citrate, EDTA and $\mathrm{Na}_{2} \mathrm{Co}_{3}$. Yin et al. (1997) stated that, changes in phosphate, nitrate, calcium, irradiance and temperature all caused quantitative, but not qualitative, changes in toxin composition produced by the cyanobacterium Lyngbyawollei

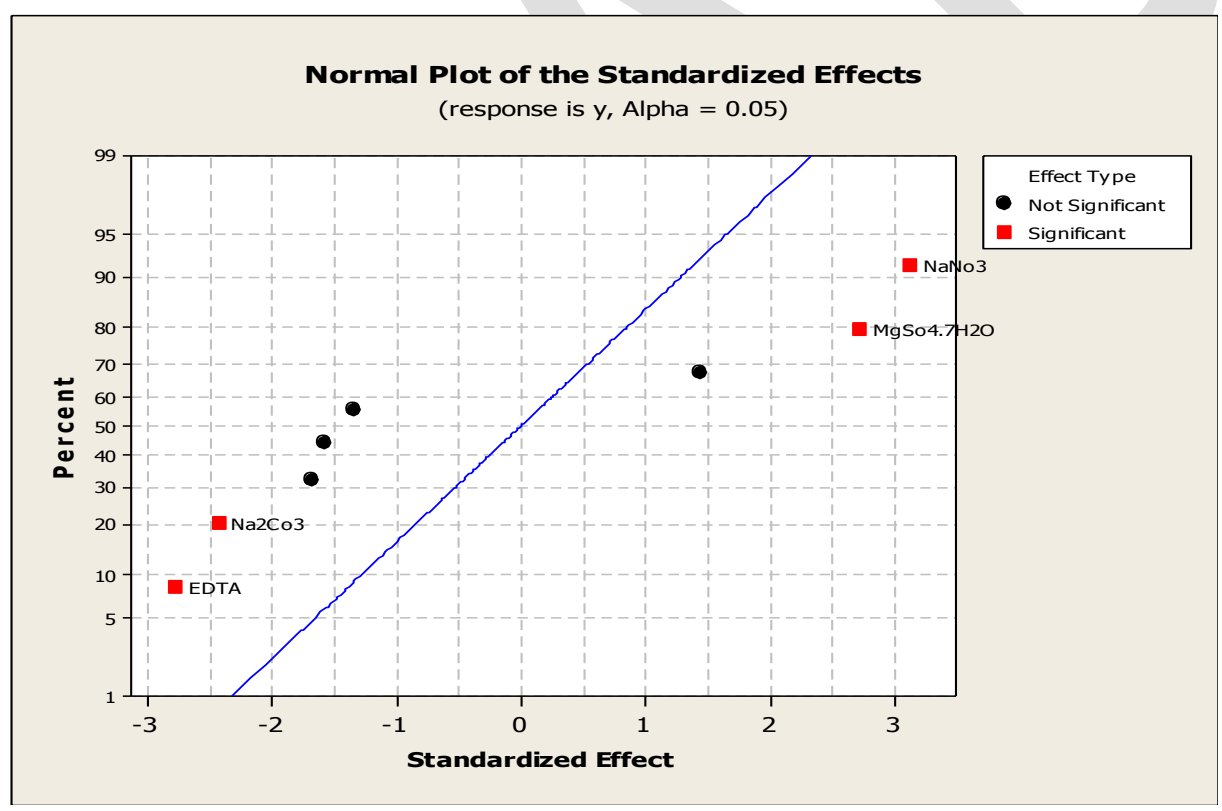

Fig.3.Normal plot of estimated effects for analysis of design on antibacterial activity.

By applying normal plot show the variableswas significant (had antibacterial activity against Streptococcus pyogenes ( ATCC 19615 )with positive correlation, $\mathrm{NaNo}_{3}$ and $\mathrm{MgSo}_{4} \cdot 7 \mathrm{H}_{2} \mathrm{O}$ andsignificant with negative correlation, EDTA and $\mathrm{Na}_{2} \mathrm{Co}_{3}$, nonsignificant with positive correlation, $\mathrm{CaCl}_{2} \cdot 2 \mathrm{H}_{2} \mathrm{O}$ and nonsignificant with negative correlation, $\mathrm{K}_{2} \mathrm{HPo}_{4}$, Citric acid and Ferric ammonium citrate. Ohtaet al., (1995) observed that the increase in magnesium concentrations cause increase in antibiotic production from Chlorococcunstrain HS-101.. 


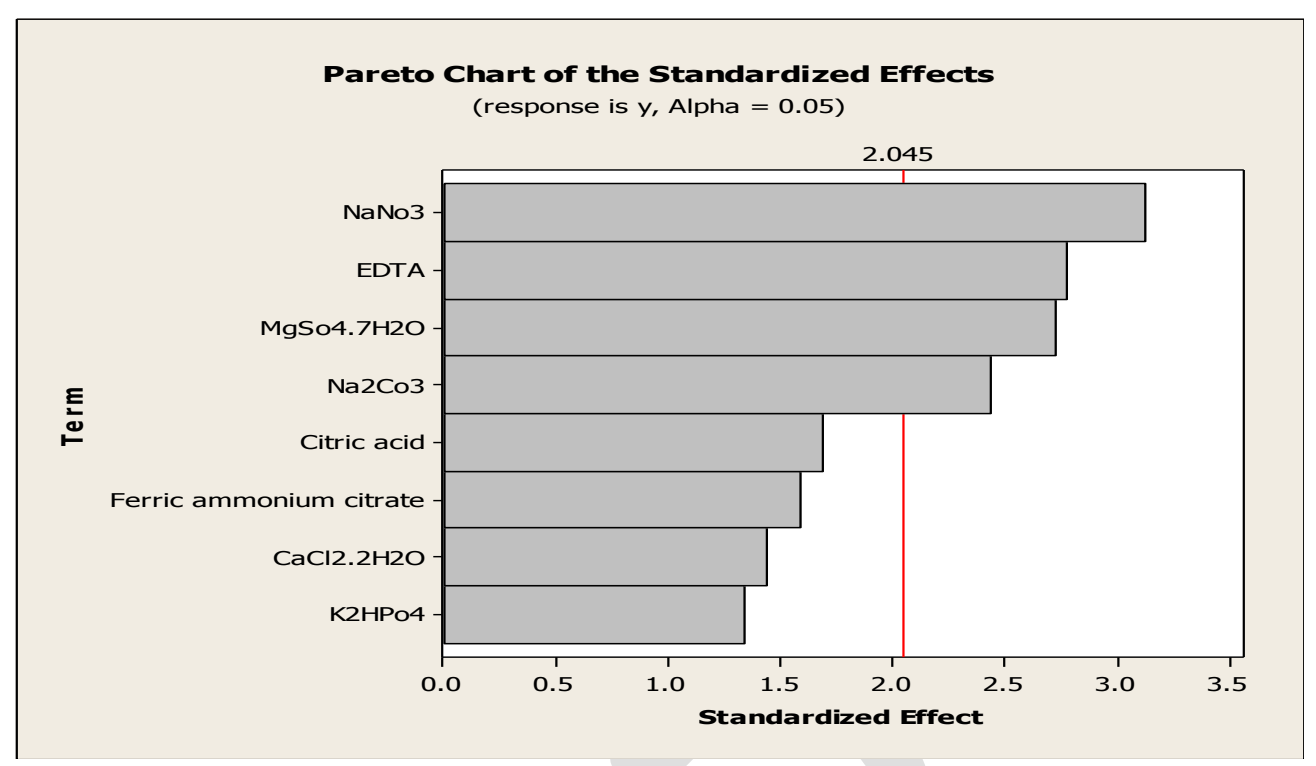

Fig.4 .Pareto chart of estimated effects for analysis of Plackett-Burman design on bioactivity of EPS against Streptococcus pyogenes(ATCC 19615 ).

Pareto chartrefers to $\mathrm{NaNO}_{3}$ is the with Bloor and England (1991) the most effective factor versus to $\mathrm{K}_{2} \mathrm{HPo}_{4}$ with the least effect on polysaccharide as antibacterial activity. This results agree increasing of nitrate from its base level of $8.8 \mathrm{mM}$ to $26.4 \mathrm{mM}$ increased the antibiotic production by Nostocmuscorum. 
Table 6. Estimated effects and coefficients for analysis of Plackett-Burman design onExopolysaccharide productionof Aphanocapsa $s p$.

\begin{tabular}{|l|l|l|l|l|l|}
\hline Term & Effect & Coef & SE Coef & $\mathrm{T}$ & P \\
\hline Constant & & 7.568 & 0.3313 & 22.85 & 0.000 \\
\hline Ammonium Chloride & -0.182 & -0.091 & 0.3313 & -0.27 & 0.786 \\
\hline $\mathrm{k}_{2} \mathrm{HPo}_{4}$ & 3.018 & 1.509 & 0.3313 & 4.56 & 0.000 \\
\hline $\mathrm{MgSO}_{4} \cdot 7 \mathrm{H}_{2} \mathrm{O}$ & 0.965 & 0.482 & 0.3313 & 1.46 & 0.156 \\
\hline $\mathrm{CaCl}_{2} \cdot 2 \mathrm{H}_{2} \mathrm{O}$ & 0.602 & 0.301 & 0.3313 & 0.91 & 0.371 \\
\hline Citric acid & 0.348 & 0.174 & 0.3313 & 0.53 & 0.603 \\
\hline Ferric ammonium citrate & -1.052 & -0.526 & 0.3313 & -1.59 & 0.123 \\
\hline EDTA & 1.615 & 0.808 & 0.3313 & 2.44 & 0.021 \\
\hline $\mathrm{Na}_{2} \mathrm{Co}_{3}$ & 1.502 & 0.751 & 0.3313 & 2.27 & 0.031 \\
\hline
\end{tabular}

The data obtained in table- 6 shows the probabilities ( $\mathrm{p}$ - value ) that measures the evidence against the null hypothesis, the lower p- value ( EDTA and $\mathrm{Na}_{2} \mathrm{Co}_{3}$ ) provide stronger evidence against the null hypothesis or significance. Whereas, the higher $\mathrm{p}$ - value ( Ferric ammonium citrate, $\mathrm{MgSo}_{4} \cdot 7 \mathrm{H}_{2} \mathrm{O}, \mathrm{CaCl}_{2} \cdot 2 \mathrm{H}_{2} \mathrm{O}$, Citric acid and Ammonium chloride) indicate insignificance effect on the Exopolysaccharide production of Aphanocapsa sp.

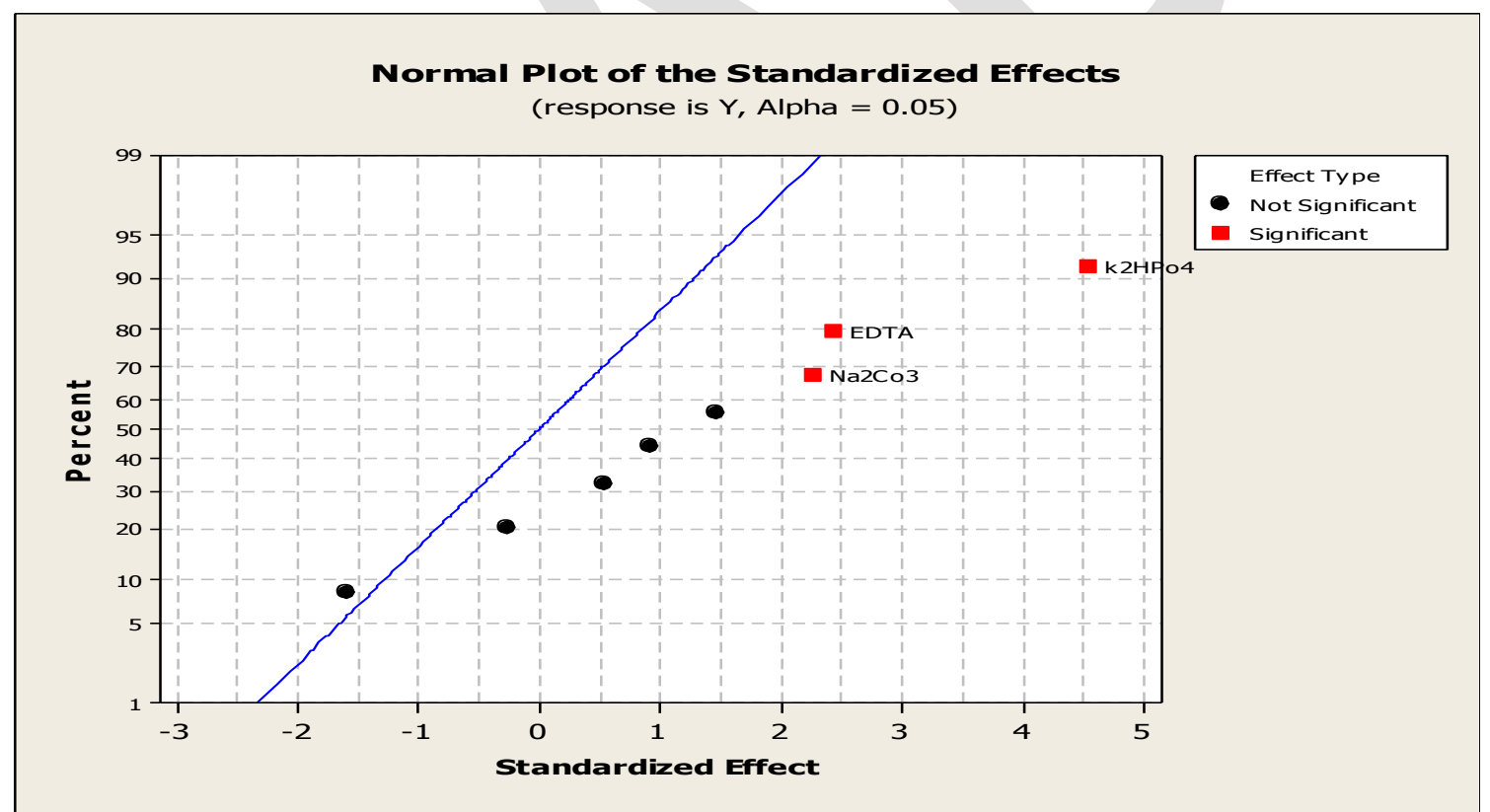

Fig.5.Normal plot of Estimated effects for analysis of Plackett-Burman design onexopolysaccharide production of Aphanocapsa sp. 


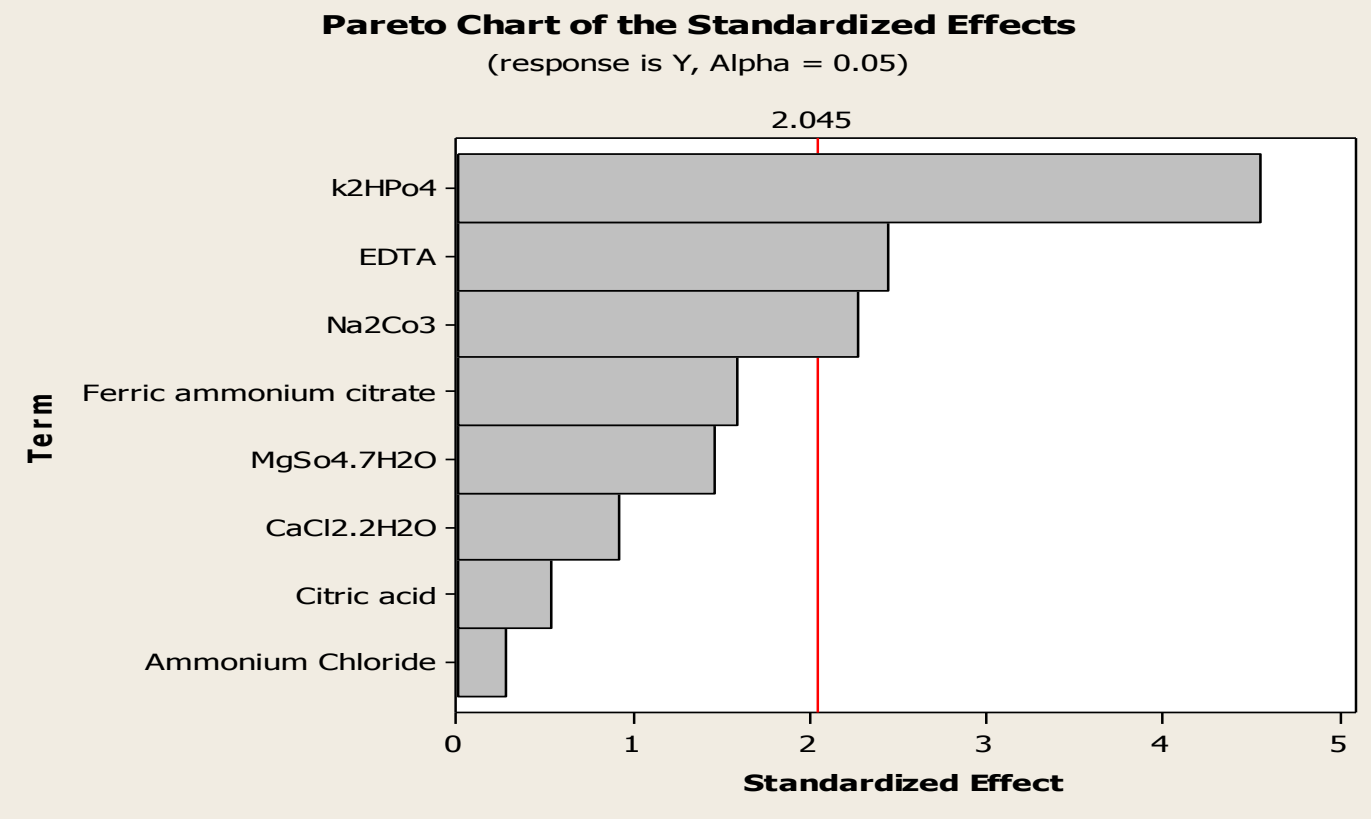

Fig.6 .Pareto chart of Estimated effects for analysis of Plackett-Burman design on Biomass of Aphanocapsa sp

The pareto chart shows that $\mathrm{Na}_{2} \mathrm{Co} 3$ has the largest effect on exopolysaccharide formation while Ammonium chloride has the smallest effect, Effects are closely

related to means, The effect is the mean for that level minus the overall mean for the factor.

Table 7. Estimated effects and coefficients for analysis of Plackett-Burman design on EXP that antibacterial activity against Streptococcus pyogenes (ATCC 19615)

\begin{tabular}{|l|l|l|l|l|l|}
\hline Term & Effect & Coef & SE Coef & T & P \\
\hline Constant & & 1.858 & 0.09258 & 20.07 & 0.000 \\
\hline Ammonium Chloride & -2.383 & -1.192 & 0.09258 & -12.87 & 0.000 \\
\hline $\mathrm{k}_{2} \mathrm{HPo}_{4}$ & 0.717 & 0.358 & 0.09258 & 3.87 & 0.001 \\
\hline $\mathrm{MgSo}_{4} .7 \mathrm{H} 2 \mathrm{O}$ & -1.061 & -0.531 & 0.09258 & -5.73 & 0.000 \\
\hline $\mathrm{CaCl}_{2} .2 \mathrm{H}_{2} \mathrm{O}$ & 1.939 & 0.969 & 0.09258 & 10.47 & 0.000 \\
\hline Citric acid & -0.717 & -0.358 & 0.09258 & -3.87 & 0.001 \\
\hline Ferric ammonium citrate & 1.050 & 0.525 & 0.09258 & 5.67 & 0.000 \\
\hline EDTA $_{\mathrm{Na}_{2} \mathrm{Co}_{3}}$ & 0.717 & 0.358 & 0.09258 & 3.87 & 0.001 \\
\hline
\end{tabular}

All the factors were proved to be significant onactivity of Aphanocapsa $s p$. Exopolysaccharide. The increase in $\mathrm{K}_{2} \mathrm{HPo}_{4}$, $\mathrm{CaCl}_{2} \cdot 2 \mathrm{H}_{2} \mathrm{O}$, Ferric ammonium citrate, EDTA and $\mathrm{Na}_{2} \mathrm{Co}_{3}$ corresponds to increase in exopolysaccharideactivity against Streptococcus pyogenes, while the decrease of Ammonium chloride, $\mathrm{MgSo}_{4} \cdot 7 \mathrm{H}_{2} \mathrm{O}$ and Citric acid acompanied by increase of exopolysaccharide activity. 


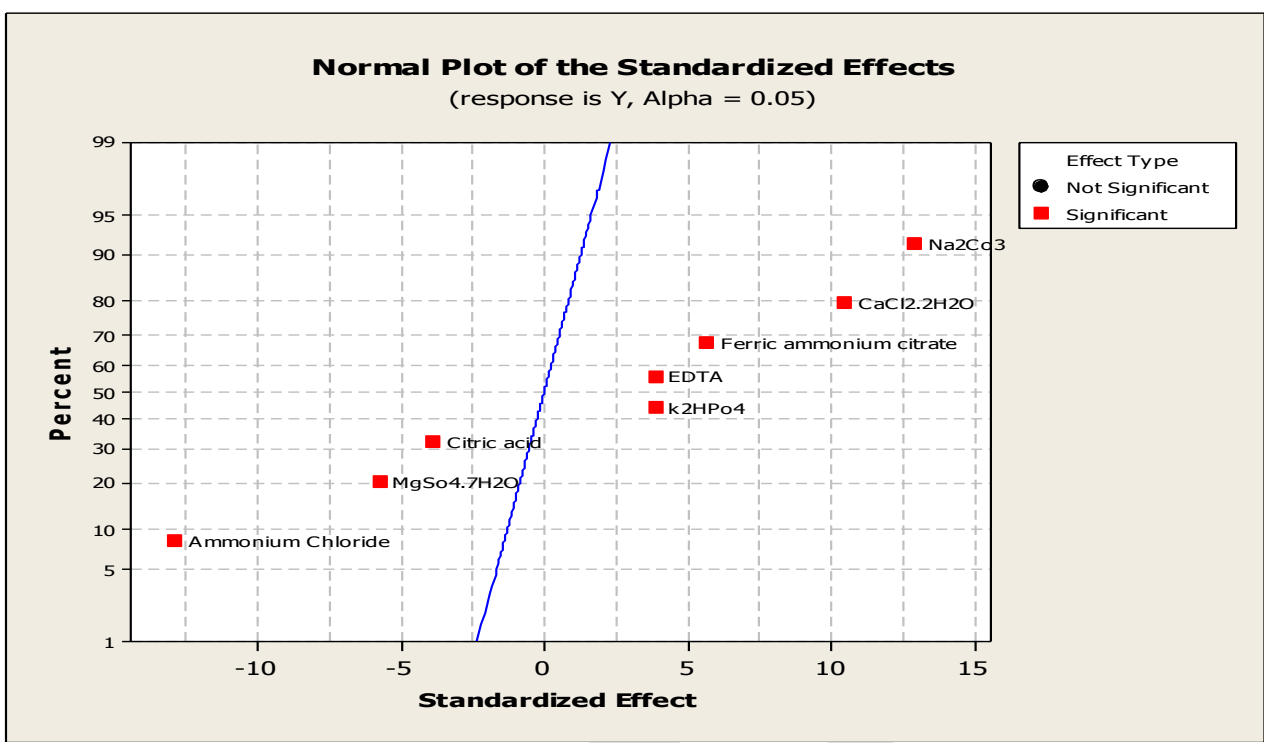

Fig.7.Normal plot of Estimated effects for analysis of Plackett-Burman design onbioactivity of (EPs) extracted from Aphanocapsa sp against Streptococcus pyogenes( ATCC 19615).

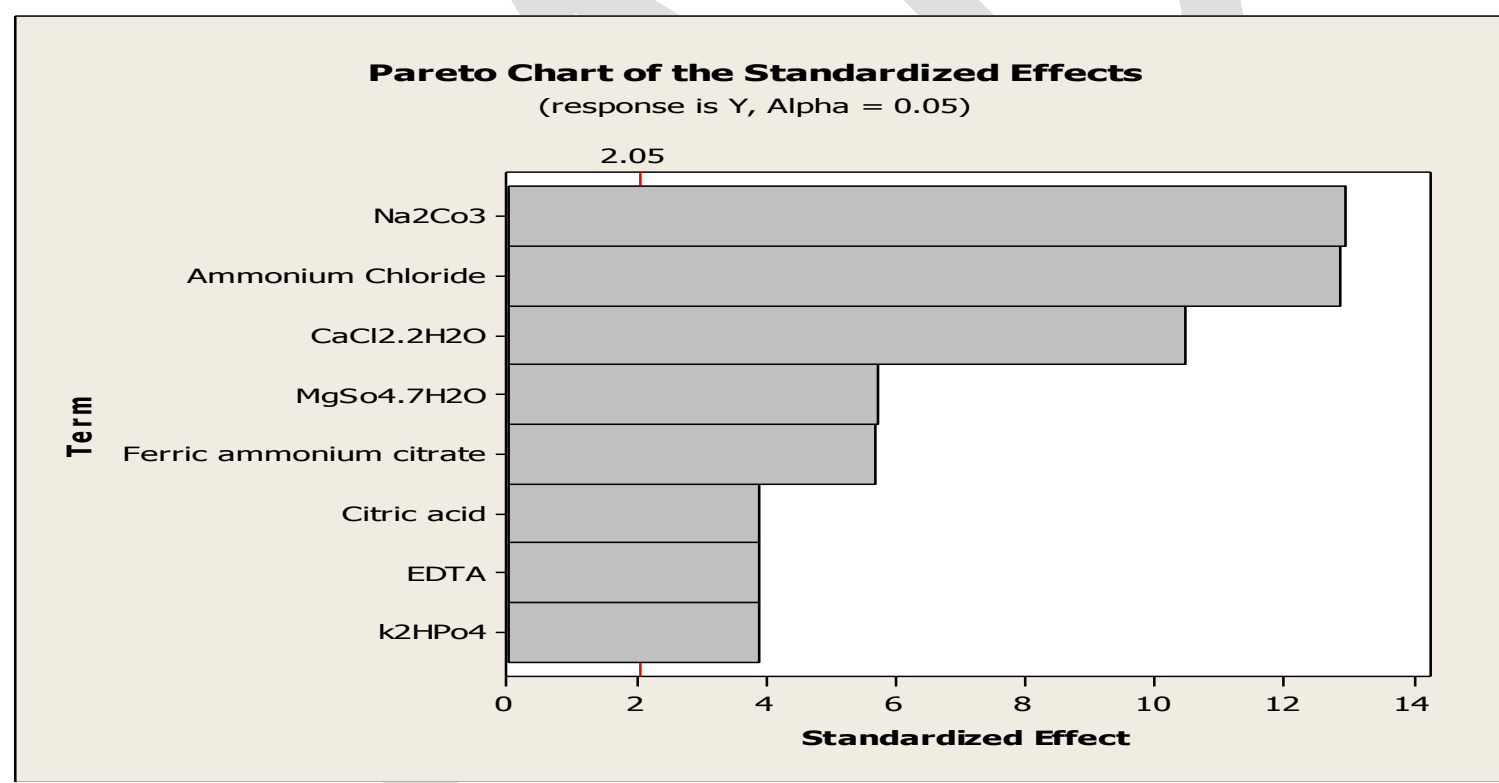

Fig.8 Pareto chart of Estimated effects for analysis of Plackett-Burman design on Exopolysaccharide activityagainst Streptococcus pyogenes( ATCC 19615).

Pareto chart ranks the detects from the largest to the smallest (Fig 8). $\mathrm{Na}_{2} \mathrm{CO}_{3}$ is the most effective factor on Exopolysaccharide activity againstStreptococcus pyogenes

(ATCC 19615) versus to $\mathrm{K}_{2} \mathrm{HPo}_{4}$.Exopolysaccharidesof $L$.

subnudusis a bioactive secondary metabolite that possesses antibacterial properties which can be explored in the treatment of bacterial infections (Majolagbe et al.,2013)

\section{CONCLUSION:}

The results of these study revealed that Eexopolysaccharide extracted fromAphanocapsa $s p$ had activity against Streptococcus pyogenes( ATCC 19615).

BG11 medium supplemented with Ammonium Chloride shows a better results for Exopolysaccharide production from 
Aphanocapsa $s p$ than medium supplemented with Sodium nitrate .Exopolysaccharide production by Aphanocapsasp had antibacterial activity, and Plackett-Burman design proved to be effective in detecting which variables are more significant. REFERENCES

Andersen, R.A., 2005. Algal Culturing Techniques. Academic Press, USA., ISBN: 9780 120884261, Pages: 578.

Chandru S1*, Jenitta Hephzibah A2, Rajesh P1 and Rajesh Kannan V1, 2013. Screening, evaluation of vibriocidal activity and characterization of bioactive substance from marine cyanobacteria . African Journal of Microbiology Research ISSN 1996-0808 Vol. 7(17), pp. 1681-1687. Pages: 686.

De Pauw, N.; Persoone, G. Microalgae for aquaculture. In Microalgal Biotechnology; Borowitzka, M.A., Borowitzka, L.J., Eds.; Cambridge University: Cambridge, UK, 1988; pp. 197221.

De Pauw, N.; Persoone, G. Microalgae for aquaculture. In Microalgal Biotechnology; Borowitzka, M.A., Borowitzka, L.J., Eds.; Cambridge University: Cambridge, UK, 1988; pp. $197-$ 221 .

Freitas, F., V.D. Alves, M. Carvalheira, N. Costa, R. Oliveira and M.A. Reis, 2009. Emulsifying behaviour and rheological properties of the extracellular polysaccharide produced by Pseudomonas oleovoransgrown on glycerol byproduct. Carbohydr. Polym., 78: 549-556.

Hayashi, T., K. Hayashi, M. Maeda and I. Kojima, 1996b. Calcium spirulan, an inhibitor of enveloped virus replication, from a blue-green alga Spirulinaplatensis .

Kreitlow .S.,Mundt. S., Lindequist U., 1999, Cyanobacteria- A potential source of new biologically active substances. J Biotech., 70: 61-63.

Kulik M.M., 1995, The potential for using cyanobacteria (blue green algae) and algae in the biological control of plant pathogenic bacteria and fungi. Eur J Plant Path., 101 (6): 585-599.
Patterson G.M.L.,. Larsen L.K,. Moore R.E, Bioactive natural products from blue-green algae. J ApplPhycol., 1994, 6: 151-157.

Pawar, S.T., A.A. Bhosale, T.B. Gawade and T.R. Nale, 2013. Isolation, screening and optimization of exopolysaccharide producing bacterium from saline soil. J. Microbiol. Biotechnol. Res., 3: 24-31.

Plackett, R.L. and Burman, J.P. 1946. The design of optimum multifactorial experiments.Biometrika, 33, 305-325

Potts M 2002,,. The ecology of cyanobacteria their diversity time and space. In: Whitton Ba, Poots M. (eds). New York; Kluwer academic publisher, pp. 465504

Rania MAA, Hala MT (2008).Antibacterial and antifungal activity of marine cyanobacteria and green microalgae, Evaluation of medium components by placket Burman design for antimicrobial activity of Spirulinaplatensis. Glob. J. Biotechnol. Biochem. 3: 22-31.

Reddy, K.J., B.W. Soper, J. Tang and R.L. Bradley, 1996. Phenotypic variation in exopolysaccharide production in the marine, aerobic nitrogen-fixing unicellular cyanobacterium Cyanothecesp. World Microbiol. Biotechnol., 12: 311-318.

Rizvi Rimsha1*, Jain Richa1, Kumar Sheela1, Shrivastava P.N.1 and Jain Manju2 2014. Bioactive substances of cyanobacteria (Nostocmuscorum): a review. / International Journal of Pharma Sciences and Research (IJPSR) ISSN : 0975-9492 Vol 5 No 071

Sharath Chandra K. and M. Rajashekhar 2013 . Antimicrobial activity of freshwater cyanobacteria isolated from pharmaceutical wastes.

African Journal of Microbiology Research. ISSN 1996-0808 Vol. 7(17), pp. 1757-1765

Steiner, R.Y., Kunisawa, R., Mandel, M., Cohen-Bazire, G., 1971. PuriWcation and properties of unicellular blue-green algae (Order Chroococcales). Bacteriol. Rev. 35, 171-205. 
V. Dvornyk and E. Nevo , 2003, Genetic polymorphism of cyanobacteria under permanent stress: A lesson from the "Evolution Canyons". Res Microbiol., 154: 79-84.

Van Landingham, S.L. and G.B. Collins, 1982. Guide to the identification, environmental requirements and pollution tolerance of freshwater blue-green algae (Cyanophyta). EPA-600/3-S2-073, Environmental Monitoring and Support Laboratory, Office of Research and
Development, US Environmental Protection Agency, USA.

Majolagbe, R.O.N,LadokeAkintola, Ogbomoso, Oyo State, Nigeria., 2013 Tel: +2348038360759. 47 Study on the Antibacterial Activity of Exopolysaccharides of Lentinussubnudus Using Swiss Albino Rats as Animal Model O.N. Majolagbe, J.K. Oloke, E.A. Adebayo, 111 A.G. Adewoyin, A. Ayandele and C.O. Bamigboye AmericanEurasian Journal of Scientific Research 8 (1): 47 